\title{
Erratum to: A Novel Flap Technique for Repairing Large Lower Lip Defects
}

\author{
Gurkan Kayabasoglu • Alpen Nacar • \\ Shan R. Baker
}

Published online: 18 February 2015

(C) Springer Science+Business Media New York and International Society of Aesthetic Plastic Surgery 2015

\section{Erratum to: Aesth Plast Surg}

DOI 10.1007/s00266-014-0438-8

The correct affiliation for Alpen Nacar is Danbury Hospital, Danbury, CT, USA. The author regrets the error.

The online version of the original article can be found under doi:10.1007/s00266-014-0438-8.

G. Kayabasoglu ( $\square)$

Otolaryngology Head and Neck Surgery Department, Sakarya

University Medical School, Adnan Menderes Cad No. 145,

Adapazari, Sakarya, Turkey

e-mail: kayabasoglu@yahoo.com; gurkan@kayabasoglu.com
A. Nacar
Danbury Hospital, Danbury, CT, USA
e-mail: alpennacar@gmail.com

S. R. Baker

Otolaryngology, Head and Neck Surgery and Facial Plastic

Surgery Department, University of Michigan, Ann Arbor,

MI, USA

e-mail: shanb@med.umich.edu 